NBER WORKING PAPER SERIES

\title{
INVESTMENT RAMIFICATIONS OF \\ DISTORTIONARY TAX SUBSIDIES
}

James R. Hines Jr.

\author{
Working Paper 6615 \\ http://www.nber.org/papers/w6615
NATIONAL BUREAU OF ECONOMIC RESEARCH 1050 Massachusetts Avenue
Cambridge, MA 02138
June 1998

I thank Austin Nichols for outstanding research assistance, and Alan Auerbach, David Cutler, Kathryn Dominguez, Takeo Hoshi, and Ronen Israel for helpful comments on an earlier draft. Any opinions expressed are those of the author and not those of the National Bureau of Economic Research.

(C) 1998 by James R. Hines Jr. All rights reserved. Short sections of text, not to exceed two paragraphs, may be quoted without explicit permission provided that full credit, including $\mathbb{C}$ notice, is given to the source. 
Investment Ramifications of Distortionary

Tax Subsidies

James R. Hines Jr.

NBER Working Paper No. 6615

June 1998

JEL No. H25, G31, G33

\begin{abstract}
This paper examines the investment effects of tax subsidies for which some assets and not others are eligible. Distortionary tax subsidies encourage firms to concentrate investments in taxfavored assets, thereby reducing the expected pre-tax profitability of investment and reducing payoffs to bondholders in the event of default. Anticipation of asset substitution makes borrowing more expensive, which in turn discourages investment. Borrowing rates react so strongly that aggregate investment may rise very little, or even fall, in response to higher tax credits. Observed positive corporate bond market reactions to events surrounding passage of the U.S. Tax Reform Act of 1986 are consistent with the model's implications.
\end{abstract}

James R. Hines Jr.

University of Michigan Business School

701 Tappan Street

Ann Arbor, MI 48109-1234

and NBER

jrhines@umich.edu 


\section{Introduction.}

Governments frequently use tax policies to encourage certain activities and discourage others. Higher rates of taxation generally reduce aggregate business investment, but it is common for certain assets to receive preferential tax treatment designed to enhance their attactiveness to investors. In the United States, the prevailing view of such preferences is decidedly skeptical; nevertheless, the current U.S. tax code offers special incentives for foreign investment, investment in $R \& D$, and other restricted categories of activity. In the years before 1987, the use of special incentives was considerably more widespread.

This paper examines the impact of tax incentives that are limited to specific categories of investments. The results indicate that, if there is a chance that firms will default on their debts, these tax incentives have significantly smaller effects on aggregate investment than they do when firms are certain not to default. Indeed, there are plausible circumstances in which higher tax subsidy rates may reduce total investment by firms receiving the incentives. The reason is that tax preferences for specific activities indirectly discourage others by worsening the conflict of interest between shareholders and bondholders. Bondholders do not benefit from investment tax incentives, since the state of the world about which they are most concerned - bankruptcy - is one in which tax incentives are valueless since firms have no tax liabilities.

If a firm loses money and is unable to pay off its debts, bondholders may be able to claim the firm's assets (net of its operating losses and any costs associated with bankruptcy). Conflict of interest stems from anticipation of this possibility, since shareholders, who control firms, invest in assets to maximize returns in those states of the world in which they, and not bondholders, are the residual claimants. Optimizing equity investors allocate resources between assets so as to equalize aftertax marginal returns. Bondholders prefer that firms equalize before-tax marginal returns, since such a rule maximizes the value of the firm if in default. Since the bond market anticipates that shareholder-controlled firms invest to maximize aftertax returns, borrowing rates rise in response to the introduction of specific investment tax incentives. Higher interest rates, in turn, reduce profits and make investment more costly. It is possible that interest rate reactions are so powerful that firms reduce total investment in response to greater incentives.

The agency problems between bondholders and shareholders generate inefficient outcomes that could be avoided if borrowers and lenders had perfect information about present and future conditions and could use enforceable and complete debt contracts specifying the types of investments firms are permitted to undertake. An efficient contract would appropriately weight the interests of both bondholders and shareholders. Such contracts are rarely if ever used in practice, which suggests either that their informational requirements are excessive or that their enforcement costs are prohibitive. The model analyzed in the paper assumes that lenders do not have sufficient information to write bond covenants that avoid the agency problems created by tax incentives.

Alternatively, the agency problems created by debt contracts could be avoided by 
financing firms entirely by equity, but doing so means relinquishing the tax benefits of debt described by Modigliani and Miller (1963) and Stiglitz (1973), and foregoing access to an important market for funds.

The apparent inability of tax incentives to stimulate aggregate investment spending is one of the major puzzles in the empirical investment literature. ${ }^{1}$ Part of the solution may lie in the noisiness of investment data, empirical specifications that are insensitive to decisionmaking lags and adjustment costs, the importance of cash flow and other omitted variables, and the endogeneity of capital asset prices to investment demand. ${ }^{2}$ This paper considers an additional possibility: that standard empirical specifications incorrectly capture the impact of tax incentives on the demand for capital. Since corporate borrowing rates reflect the bond market's anticipation of behavior that is endogenous to tax incentives, it is inappropriate to treat interest rates on corporate debt as exogenous in evaluating the effects of tax policies on investment.

Jorgenson-style cost of capital calculations imply that tax incentives for investments in specific assets affect the composition of new investment and increase the total volume of investment. These implications depend on an assumed zero probability of bankruptcy. The model in this paper implies that if there is a chance that investors will default on their debts, then these two phenomena - significant asset substitution and rapidly rising total investment - should not both accompany higher distortionary tax subsidies.

There is an extensive literature on the inability of some firms - typically, those in tax loss situations - to use various tax credits. ${ }^{3}$ Most of these situations reflect the tax law's asymmetric treatment of profits and losses. This problem is typically treated as one in which firms that act in the interest of their shareholders react little to tax subsidies if there is a substantial probability of having tax losses. There is, however, a potentially much more powerful implication of the asymmetric treatment of profits and losses that stems from the inability of creditors of bankrupt firms to use their accumulated tax credits. Neither of these implications is important if owners of unprofitable firms can benefit from tax incentives by effectively selling them to profitable firms through takeovers or sale-leaseback operations. In practice, unprofitable firms seldom benefit from tax credits; ${ }^{4}$ this paper analyzes cases in which investors anticipate that tax credits have no value to firms with tax losses.

It is well established that bond prices are correlated with a firm's profitability, ${ }^{5}$ but the distinction between pre-tax and after-tax profitability has heretofore received scant if any attention in empirical studies of bond pricing. The U.S. Tax Reform Act of 1986 removed many of the existing incentives to distort the composition of

\footnotetext{
${ }^{1}$ Chirinko (1993) surveys this literature.

${ }^{2}$ See, for example, Auerbach and Hassett (1992), Cummins et al. (1994), and Goolsbee (1998).

${ }^{3}$ See, for example, Auerbach (1983, 1986), Auerbach and Poterba (1987), Majd and Myers (1987), Mintz (1988), and Altshuler and Auerbach (1990).

${ }^{4}$ Auerbach and Reishus (1988) and Gilson (1990) note the infrequency with which defaulting firms are acquired by profitable entities, and Hotchkiss (1995) documents the subsequent poor financial performance of bankrupt firms that undergo reorganization.

${ }^{5}$ See, for example, Kwan (1996).
} 
investment in favor of tax-preferred assets. Evidence from event days surrounding passage of the 1986 Act indicates that corporate bond prices rallied in response, even as Treasury bonds and corporate stock prices fell. Positive reactions appear to be concentrated in lower-grade corporate debt, which is consistent with a model in which corporate borrowing rates are endogenous to distortionary incentives embedded in the tax code.

Section 2 of the paper analyzes the properties of a simple model in which certain assets receive favorable tax treatment. Section 3 considers extensions of the model. Section 4 examines evidence from bond market reactions to events surrounding the passage of the U.S. Tax Reform Act of 1986. Section 5 is the conclusion.

\section{A Model.}

In order to clarify the issues raised by distortionary tax incentives, it is useful to analyze a model in which management acts in the interest of shareholders and there is no conflict between the interests of shareholders and the interests of bondholders in the absence of taxation. More general treatments of the investment problem would consider situations in which there are interactions between various agency problems, including those introduced by taxation.

\subsection{Framework.}

Consider a firm that invests in two assets, $K_{1}$ and $K_{2}$, prior to the realization of a stochastic shock to its output. For simplicity the model has only two periods; the firm chooses $K_{1}$ and $K_{2}$ in the first period, while the state of the world is revealed and contracts are closed in the second. The firm's (reduced-form) production function is $y\left(K_{1}, K_{2}\right) \theta$, in which $y(\cdot)$ is a deterministic function and $\theta \in[0, \infty]$ is the realization of the shock. The production function is taken to be concave and homothetic, which rules out unusual outcomes stemming simply from output scale effects. Output is assumed to be verifiable to all investors. $\theta$ is distributed according to a known density function $g(\theta)$.

Firms are assumed to be risk-neutral, in the sense that managers maximize expected profits without regard to the correlation between $\theta$ and the market return. Alternatively, one can think of $\theta$ as reflecting purely idiosyncratic shocks to a firm's production function.

Assets 1 and 2 each depreciate at one-period rate $\delta .^{6}$ The firm's investments are financed by a combination of owner's equity (E) and bonds (B) held by unrelated parties. Aggregate firm capital is denoted $\mathrm{K} \equiv \mathrm{K}_{1}+\mathrm{K}_{2}$; the firm's capital constraint is the requirement that $K \leq E+B$.

\footnotetext{
${ }^{6}$ As a general matter, assets depreciate at differing rates - and in particular, the history of U.S. experience with investment tax credits is that tax-favored assets tend to have higher depreciation rates. This issue is important in interpreting the empirical work presented in section 4 . Depreciation rates are assumed to be equal in this section in order to consider a situation in which there is no conflict of interest between shareholders and bondholders in the absence of special tax incentives.
} 
The shock, $\theta$, is realized at the start of the second period. The realization of $\theta$ influences both the pre-tax profitability of the firm and its tax liability. There are three possible outcomes in the second period. The first possibility is that the firm is profitable and has positive tax liability. If so, the firm pays corporate taxes at rate $\tau$ on its output net of interest charges and depreciation. In addition, and this is the focus of the subsequent analysis, the firm receives a tax credit of $c$ for every unit of $K_{1}$ it installs. The second possibility is that the firm has tax losses (and therefore no tax liability) but is not in default. The third possibility is that the firm's revenues are so low that it defaults on its debt obligations.

The tax credit is assumed to be nonrefundable if the firm has tax losses. Nonrefundability is at the heart of the agency problem, since the bondholders, who are residual claimants on the firm's assets in the event of default, receive no benefits from the tax credit because default is also a state in which the firm has no tax obligations.

Aggregate production is a function of $\mathrm{K}$, the total capital stock, and its allocation between assets 1 and 2 . Since the production function is homothetic, the interasset allocation of capital is independent of the scale of output, being instead a function of the relative cost of the two assets as determined by $c$. It is useful to introduce the following quasi-reduced form notation for output: $Q(K, c) \theta$, in which $Q(K, c)=$ $y\left[K \sigma_{1}(c), K\left(1-\sigma_{1}(c)\right)\right]$ and $\sigma_{1} \equiv K_{1} / K$ is the firm's share of credit-eligible capital.

A firm that borrows in the first period must redeem its debt, along with any agreed-upon interest, in the second period, unless the firm defaults, in which case bondholders are entitled to seize control of the firm and its assets. $r(B, K, c)$ denotes the required payment (in non-bankruptcy states) to debtholders in the second period, representing interest $[r(B, K, c)-B]$ plus repayment of debt principle $(B)$. As the notation indicates, interest rates are functions of total borrowing, total investing (and thereby implicitly the equity contributions of shareholders), and the incentives created by the tax system. Figure 1 depicts the sequence of events. In the first period, investors commit $\mathrm{E}$ of equity to the firm, after which the firm borrows $\mathrm{B}$ in the bond market. The firm then selects $K_{1}$ and $K_{2}$.

Shareholders of profitable, taxpaying firms receive:

$$
\{Q(K, c) \theta-[r(B, K)-B]-\delta K\}(1-\tau)-B+K+c K \sigma_{1}
$$

The term in braces is the firm's sales revenue, minus the sum of its depreciation charges and interest payments. Depreciation for tax purposes is assumed to equal economic depreciation. The second term in the expression $(-B)$ reflects the repayment of debt principle. Finally, investors have claims on the firm's capital stock and receive the tax credits associated with investing in $K_{1}$.

It is possible that the firm's earnings will be sufficient to cover its required payment of $r(B, K, c)$ to bondholders but insufficient to generate positive tax liability, either because the firm incurs losses or because its tax credits $\left(c K \sigma_{1}\right)$ equal or exceed its 
tax liabilities. ${ }^{7}$ Since the firm pays no taxes, shareholders receive:

$$
Q(K, c) \theta+(1-\delta) K-r(B, K, c) .
$$

The third possibility is that the firm's losses are so great that bondholders cannot be fully paid off; instead, bondholders receive the firm's assets (net of operating losses and bankruptcy costs) and shareholders receive nothing in the second period.

Shareholder expected profits $\left(\pi^{e}\right)$ are:

$$
\begin{aligned}
\pi^{e}= & \left\{\left[Q(K, c) \theta_{1}-r(B, K, c)-\delta K\right](1-\tau)-B \tau+K+c K \sigma_{1}\right\} p_{1} \\
& +\left\{Q(K, c) \theta_{2}-r(B, K, c)+(1-\delta) K\right\} p_{2}
\end{aligned}
$$

in which $p_{1}$ denotes the support of the distribution of $\theta$ over which the firm has positive tax liability and $\theta_{1}$ is the average value of $\theta$ within that region. Similarly, $p_{2}$ denotes the support of the distribution of $\theta$ over which the firm meets its debt obligations but has no tax liability; $\theta_{2}$ is the average value of $\theta$ within that region. For notational simplicity it is convenient to treat $\theta$ as though it has a point distribution taking the value $\theta_{1}$ with probability $p_{1}$, the value $\theta_{2}$ with probability $p_{2}$, and the value $\theta_{3}$ with probability $p_{3}$, in which $p_{1}+p_{2}+p_{3}=1$ and $p_{3}$ is the probability of default. $^{8} p_{1}$ is defined to equal the probability of $\theta$ falling in the range that:

$$
\tau\{Q(K, c) \theta-[r(B, K, c)-B]-\delta K\}-c K \sigma_{1}>0 .
$$

$p_{2}$ is defined to equal the probability of $\theta$ falling in the range that:

$$
\begin{aligned}
\tau\{Q(K, c) \theta-[r(B, K, c)-B]-\delta K\}-c K \sigma_{1} & \leq 0 \\
Q(K, c) \theta+(1-\delta) K-r(B, K, c) & \geq 0 .
\end{aligned}
$$

Expected returns as defined in (1) are operating returns that make no allowance for the cost of invested equity (E). Denote the oppotunity cost of equity (measured in second period units) by $\rho$. The firm chooses $\mathrm{K}_{1}, \mathrm{~K}_{2}, \mathrm{~B}$, and $\mathrm{E}$ to maximize:

$$
\pi^{e}-\rho E
$$

subject to:

$$
E+B \geq K \text {. }
$$

The first-order condition corresponding to maximizing (2) over the choice of $\mathrm{K}$, subject to (3), is:

$$
\frac{\partial Q}{\partial K}\left[p_{1} \theta_{1}(1-\tau)+p_{2} \theta_{2}\right]+\left[(1-\delta)-\frac{\partial r}{\partial K}\right]\left[p_{1}(1-\tau)+p_{2}\right]+p_{1} \tau+p_{1} \sigma_{1} c=\lambda
$$

\footnotetext{
${ }^{7}$ This statement assumes that taxpayers are entitled to use tax credits to offset $100 \%$ of their tax liabilities. In practice, many countries (including the United States) limit the extent to which certain kinds of tax credits can be so used. Explicitly incorporating such restrictions would change the analysis very little.

${ }^{8}$ Note that, since $\theta$ takes nonnegative values, $\theta_{1} \geq \theta_{2} \geq \theta_{3} \geq 0$. The appendix analyzes the model in a setting in which $\theta$ is distributed continuously, making the probability of default (as well as $p_{1}$ and $p_{2}$ ) endogenous to tax polices and to investment decisions of firms. The results are identical to those described in the text (in which $\theta$ is distributed discretely).
} 
in which $\lambda \geq 0$ is the lagrange multiplier corresponding to the value of the constraint (3). In addition, there are two first order conditions corresponding to alternative sources of finance:

$$
\frac{\partial r}{\partial B}\left[p_{1}(1-\tau)+p_{2}\right]-p_{1} \tau=\lambda
$$

which must be satisfied for firms issuing positive amounts of debt, and

$$
\rho=\lambda
$$

for firms with positive equity. In equilibrium, firms using both debt and equity must be indifferent between them (as in Miller (1977) and DeAngelo and Masulis (1980)). Market equilibrium is characterized by firms with internal debt-equity ratios that generate probabilities of bankruptcy making them indifferent at the margin between the two sources of finance. In order to evaluate the role of tax parameters in influencing the cost of debt (and therefore also equity) finance, it is necessary to consider the nature of equilibrium in the bond market.

\subsection{Bond Market Equilibrium.}

Interest rates on risky debt reflect the requirement that lenders receive risk-adjusted normal returns. Bondholders receive $r(B, K, c)$ if the firm is solvent in period two, and receive less if the firm is insolvent. Bondholders of bankrupt firms are entitled to seize their assets, though the process of doing so typically entails some costs. Recognizing these costs, shareholders and bondholders of firms in default often prefer to settle their claims without recourse to formal bankruptcy proceedings. A simplified characterization of default is that bondholders receive in period two the firm's assets, net of its operating losses, and net of associated bankruptcy costs.

Lenders are assumed to know $\mathrm{B}$ and $\mathrm{K}$, but not to be able to contract over the breakdown of $\mathrm{K}$ into $\mathrm{K}_{1}$ and $\mathrm{K}_{2}$. Denoting the required certainty-equivalent rate of interest by $\bar{r}$, bond market equilibrium requires that

$$
(1+\bar{r}) B=\left(p_{1}+p_{2}\right) r(B, K, c)+p_{3}\left[Q(K, c) \theta_{3}+(1-\delta) K\right]
$$

in which the first term on the right side of (7) is the payoff to bondholders in nonbankruptcy states, and the second term is the payoff in bankruptcy. For the purpose of this expression, any bankruptcy costs are assumed to be incorporated in the relevant value of $\theta_{3}$. Differentiating ( 7 ,

$$
\frac{\partial r}{\partial K}=\frac{-p_{3}}{1-p_{3}}\left[\frac{\partial Q(K, c)}{\partial K} \theta_{3}+(1-\delta)\right]
$$

and

$$
\frac{\partial r}{\partial B}=\frac{1+\bar{r}}{1-p_{3}} .
$$

Equation (9) reflects that additional borrowing yields bondholders (in aggregate) no additional returns in bankruptcy states, since bondholders receive simply the value 
of the firm (minus bankruptcy costs), which is unaffected by the amount of capital raised on the debt market.

By contrast, (8) illustrates that new investment reduces interest rates, since, with $B$ held constant, any additional investment is financed with equity. Equityfinanced investments reduce the severity of bankruptcy outcomes from the standpoint of bondholders, though the extent to which new investments reduce interest rates is a function of differences between shareholder and bondholder interests induced by nonzero values of $c$.

\subsection{Investment Implications.}

Combining (4), (5), (8), and (9),

$$
\frac{\partial Q(K, c)}{\partial K}\left[p_{1} \theta_{1}(1-\tau)+p_{2} \theta_{2}+\frac{p_{3}\left[p_{1}(1-\tau)+p_{2}\right]}{p_{1}+p_{2}} \theta_{3}\right]=\frac{(\bar{r}+\delta)\left[p_{1}(1-\tau)+p_{2}\right]}{p_{1}+p_{2}}-c \sigma_{1} p_{1}
$$

This equation is standard in the Hall-Jorgenson analysis of investment, since if $p_{1}=1$ and $p_{2}=p_{3}=0$, then it simply implies that $\frac{\partial Q(K, c)}{\partial K} \theta_{1}=\bar{r}+\delta-c \sigma_{1} /(1-\tau)$. In that setting, changes in $c$ have direct impact on the marginal product of capital and an implied effect on capital demand. Earlier studies analyze the importance of $p_{2}>0$ in reducing the impact of $c$ on investment. In the setting described by (10), however, $p_{3}>0$ has much greater potential to affect the impact of $c$ on capital demand than does $p_{2}>0$.

Since the influential work of Hall and Jorgenson (1967), it is customary to evaluate the investment effects of tax policies by calculating tax-induced changes in the cost of capital. In equation (10), the cost of capital appears as $\frac{\partial Q(K, c)}{\partial K}$, the tax-induced marginal product of capital.

Decomposing the effect of $c$ on $\frac{\partial Q(K, c)}{\partial K}$,

$$
\frac{d\left[\frac{\partial Q(K, c)}{\partial K}\right]}{d c}=\frac{\partial^{2} Q(K, c)}{\partial K^{2}} \frac{d K}{d c}+\frac{\partial Q^{2}(K, c)}{\partial K \partial c}
$$

in which the first term on the right side of (11) is the change in the cost of capital due to interactions between changes in investment levels and the concavity of the production function, and the second term on the right side is the change in the marginal product of capital induced by substitution of $K_{1}$ for $K_{2}$. Since the effect of $c$ on output, holding $K$ fixed, stems from induced changes in the composition of capital inputs, it follows that

$$
\frac{\partial Q(K, c)}{\partial c}=\left[\frac{\partial y}{\partial K_{1}}-\frac{\partial y}{\partial K_{2}}\right] K \frac{d \sigma_{1}}{d c}
$$

It is straightforward to establish, in a manner similar to the derivation of (4), that the firm's profit-maximizing choice of $K_{1}$ and $K_{2}$ satisfies:

$$
\frac{\partial y}{\partial K_{1}}-\frac{\partial y}{\partial K_{2}}=\frac{-c p_{1}}{p_{1} \theta_{1}(1-\tau)+p_{2} \theta_{2}} \text {. }
$$


Since the right side of (13) is independent of $K$, it follows that (12) implies:

$$
\frac{\partial^{2} Q(K, c)}{\partial K \partial c}=\left[\frac{\partial y}{\partial K_{1}}-\frac{\partial y}{\partial K_{2}}\right] \frac{d \sigma_{1}}{d c} .
$$

Totally differentiating (10) yields:

$$
\frac{d\left(\frac{\partial Q(K, c)}{\partial K}\right)}{d c}=\frac{-p_{1}\left(\sigma_{1}+c \frac{d \sigma_{1}}{d c}\right)}{\left[p_{1} \theta_{1}(1-\tau)+p_{2} \theta_{2}+\frac{p_{3}\left[p_{1}(1-\tau)+p_{2}\right]}{p_{1}+p_{2}} \theta_{3}\right]} .
$$

Then rearranging (11), and imposing (14), (13), and (15) implies:

$$
\frac{\partial^{2} Q(K, c)}{\partial K^{2}} \frac{d K}{d c}=\frac{p_{1} c \frac{d \sigma_{1}}{d c}}{\left[p_{1} \theta_{1}(1-\tau)+p_{2} \theta_{2}\right]}-\frac{p_{1}\left(\sigma_{1}+c \frac{d \sigma_{1}}{d c}\right)}{\left[p_{1} \theta_{1}(1-\tau)+p_{2} \theta_{2}+\frac{p_{3}\left[p_{1}(1-\tau)+p_{2}\right]}{p_{1}+p_{2}} \theta_{3}\right]}
$$

It is useful to define a measure, $f$, of the extent to which the firm's output is expected to come in default states:

$$
f \equiv \frac{p_{3} \theta_{3}\left[p_{1}(1-\tau)+p_{2}\right]}{\left[p_{1} \theta_{1}(1-\tau)+p_{2} \theta_{2}\right]\left[p_{1}+p_{2}\right]}
$$

If default is impossible $\left(p_{3}=0\right)$ then $f=0$. If $p_{2}=0$ then $f=p_{3} \theta_{3} / p_{1} \theta_{1}$, so $f$ may exceed unity at sufficiently high default probabilities. Then letting

$$
\eta \equiv \frac{\partial \sigma_{1}}{\partial c} \frac{c}{\sigma_{1}}
$$

define the elasticity of the share of capital of type one in the firm's capital stock with respect to the tax credit, (16) becomes:

$$
-\frac{\partial^{2} Q(K, c)}{\partial K^{2}}\left[p_{1} \theta_{1}(1-\tau)+p_{2} \theta_{2}\right](1+f) \frac{d K}{d c}=p_{1} \sigma_{1}(1-f \eta) .
$$

Concavity of the production function implies that $\frac{\partial^{2} Q(K, c)}{\partial K^{2}}<0$, so $(1-f \eta)<0$ means that $\frac{d K}{d c}<0$. Higher tax credit rates reduce investment if $f \eta>1$, which arises if substantial fractions of output come in default states of the world and if firms substitute strongly toward tax-preferred assets in response to higher tax credits. These two conditions are jointly necessary, since if $f=0$, then default is impossible and there is no agency cost associated with shareholder control of the firm, while if $\eta=0$, then firms do not respond to tax credits by substituting assets in a way that is costly to bondholders.

It is noteworthy that, from its definition, $\eta=0$ if $\frac{d \sigma_{1}}{d c}=0$ or $c=0$, so either of these conditions is sufficient to guarantee that $\frac{d K}{d c}>0$. If $\frac{d \sigma_{1}}{d c}=0$ then firms do not substitute one capital good for another in response to relative price changes. If $c=0$ then bondholders are unharmed by asset substitution, since pretax marginal products of different capital types are equal. 
The term $(1-f \eta)$ in $(17)$ is the factor by which excessive asset substitution reduces the investment impact of specific tax subsidies. ${ }^{9}$ In order to evaluate the magnitude of this factor, it is useful to replace $\eta$ in with a more commonly-estimated parameter, $\varepsilon$, the elasticity of substitution between $K_{1}$ and $K_{2}$. The substitution elasticity is:

$$
\varepsilon \equiv \frac{d\left(K_{1} / K_{2}\right)}{d\left(c_{1} / c_{2}\right)} \frac{\left(c_{1} / c_{2}\right)}{\left(K_{1} / K_{2}\right)}
$$

in which $c_{1}$ is the user cost of capital goods of type one and $c_{2}$ is the user cost of capital goods of type two. From its definition, $\sigma_{1}=\frac{K_{1}}{K_{1}+K_{2}}=\frac{K_{1} / K_{2}}{1+\left(K_{1} / K_{2}\right)}$. Furthermore, homotheticity of the production function implies that $\frac{d\left(K_{1} / K_{2}\right)}{d c}=\frac{d\left(K_{1} / K_{2}\right)}{d\left(c_{1} / c_{2}\right)} \frac{d\left(c_{1} / c_{2}\right)}{d c}$, since ratios of factor inputs are affected by relative costs but not by output levels. Consequently,

$$
\frac{d \sigma_{1}}{d c}=\frac{\frac{d\left(K_{1} / K_{2}\right)}{d\left(c_{1} / c_{2}\right)} \frac{d\left(c_{1} / c_{2}\right)}{d c}}{\left[1+\left(K_{1} / K_{2}\right)\right]^{2}}=\frac{\varepsilon \sigma_{1}\left(1-\sigma_{1}\right) \frac{d\left(c_{1} / c_{2}\right)}{d c}}{\left(c_{1} / c_{2}\right)} .
$$

From the standard Hall-Jorgenson formula, the user cost of capital of type one, for an investment financed by equity, is: $c_{1}=\left(r^{e}+\delta\right)(1-c-\tau z) /(1-\tau)$, in which $r^{e}$ is the appropriately-adjusted required rate of return on equity investment, and $z$ is the present discounted value of depreciation allowances. It is appropriate to use this expression because firms are indifferent at the margin between financing investments with debt and with equity. It follows that $c_{1} / c_{2}=(1-c-\tau z) /(1-\tau z)$, which in turn implies that $\frac{d\left(c_{1} / c_{2}\right)}{d c}=-1 /(1-\tau z)$. Finally, the present value of economic depreciation allowances is given by $z=\frac{\delta}{\bar{r}+\delta}$ (Hall and Jorgenson, 1971). These substitutions yield:

$$
\eta=\frac{-\varepsilon\left(1-\sigma_{1}\right) c}{1-c-\frac{\tau \delta}{\vec{r}+\delta}}
$$

High values of $f$ and $c$, and large negative values of $\varepsilon$, conspire greatly to reduce $\frac{d K}{d c}$. For example, if $f=1, \sigma_{1}=0.2, c=0.3, \tau=0.45, \delta=.10, \bar{r}=0.05$, and $\varepsilon=-1$, then $(1-f \eta)=0.4$. With otherwise the same parameters but $\varepsilon=-2$, $(1-f \eta)=-0.2$. At higher absolute values of $\varepsilon$, asset substitution means that small increments to $c$ will be accompanied by significant shifting of investment into taxfavored assets with relatively low pre-tax marginal products. Higher values of $f$ likewise reduce $\frac{d K}{d c}$. While calculations can illustrate the possibility that investment falls with higher levels of $c$, the more general point is that it is necessary to adjust standard cost of capital formulas by the factor $(1-f \eta)$ in order to capture the incentives created by the tax system.

\subsection{Implications for Profitability.}

The same considerations that reduce the investment impact of specific tax credits also reduce the effect of higher tax credits on profitability. Indeed, indentical terms

\footnotetext{
${ }^{9}$ Since $p_{1}$ premultiplies the right side of $(17)$, the term $(1-f \eta)$ captures the effect of asset substitution conditional on potential unprofitability. Previous studies of invstment tax incentives when $p_{1}<1$ implicitly assume that $p_{2}=1-p_{1}$, and therefore $p_{3}=0$, so it is necessary to adjust their calculations by $(1-f \eta)$ when $p_{3}>0$.
} 
appear in both the profitability and investment equations. Higher tax credit rates raise borrowing costs as lenders anticipate substitution into tax-preferred assets. If this effect is sufficiently large, it can overwhelm the direct effect of tax credits on profitability.

Differentiating the bond market equation (7) produces:

$$
\left(p_{1}+p_{2}\right) \frac{\partial r(B, K, c)}{\partial c}+p_{3} \theta_{3} \frac{\partial Q(K, c)}{\partial c}=0,
$$

which, together with (12) and (13), implies:

$$
\frac{\partial r(B, K, c)}{\partial c}=K \frac{d \sigma_{1}}{d c} c p_{1} \frac{p_{3} \theta_{3}}{\left[p_{1} \theta_{1}(1-\tau)+p_{2} \theta_{2}\right]\left[p_{1}+p_{2}\right]} .
$$

From (1) and the envelope theorem, the effect of $c$ on expected profits is:

$$
\frac{d \pi^{e}}{d c}=-\frac{\partial r(B, K, c)}{\partial c}\left[p_{1}(1-\tau)+p_{2}\right]+K \sigma_{1} p_{1} .
$$

Then combining (21) and (22) yields:

$$
\frac{d \pi^{e}}{d c} \frac{1}{K}=p_{1} \sigma_{1}(1-f \eta)
$$

the right side of which is identical to the right side of (17). The same moral hazard costs associated with higher tax credit rates that reduce investment also reduce expected profitability. Since investors must be indifferent between holding riskless government debt and risky corporate bonds, the costs or benefits of distortionary tax incentives are borne entirely by shareholders.

Figure 2 illustrates the equivalent (and much more easily depicted) effect of tax credits on the cost of producing a given quantity of output. The two solid lines in the figure reflect after-tax relative prices of $K_{1}$ and $K_{2}$ before and after the introduction of a credit for purchases of $K_{1}$. For simplicity consider the case in which $p_{2}=0$, so that the firm is either taxable or bankrupt. The distance between the points at which the two budget lines, tangent to the same isoquant, intersect the vertical axis equals the cost reduction for which the tax credit is responsible if the firm is taxable. The dotted line in Figure 2 is constructed to be parallel to the original price line while intersecting the input combination that maximizes expected returns to shareholders after introduction of the tax credit. The distance between the points at which this line and the original budget line intersect the vertical axis equals the extent to which pre-tax input costs rise due to substitution induced by the tax credit. If the product of this higher cost and the probability of default exceeds the product of the after-tax cost reduction and the probability of being taxable, then the tax credit raises expected after-tax costs. This is possible because, with $p_{2}=0$, the input combination that maximizes shareholder value is independent of the probability of default and the value of $\theta$ in default states; consequently, shareholders have excessive incentives to substitute $K_{1}$ for $K_{2}$. If the probability of bankruptcy is sufficiently great, and the two inputs are highly substitutable, then the costs associated with asset substitution may exceed the direct benefits of receiving tax credits. 


\subsection{Relation to Other Agency Cost Models.}

The cost of the inefficiency generated by incentives to overinvest in tax-preferred assets (to the detriment of bondholders) is ultimately borne by shareholders, who are unable to commit their firms not to do so, and who therefore must pay higher interest rates. This result is similar in spirit to earlier work on incentives to distort the portfolio of investments financed using incomplete debt contracts. The option aspect of an equity claim implies that there are situations in which firms serve the interests of shareholders by making risky investments with negative expected present values and by foregoing safe investments with positive present values. ${ }^{10}$ Lenders, who understand these incentives, demand higher interest rates in response. The incentive to overinvest in risky assets is perhaps somewhat subtler than the incentive to overinvest in taxpreferred assets, though it is similar in that the conflicting interests of shareholders and bondholders distort behavior and drive up interest rates in response.

Incomplete debt contracts that distort investment decisions may simultaneously serve to correct other inefficiencies. There is considerable recent attention devoted to the use of debt to discipline managers and thereby reduce some of the agency problems between shareholders and managers. ${ }^{11}$ Debt used for this purpose nevertheless becomes more costly when some assets but not all receive preferential tax treatment.

\section{Extensions to the Model.}

This section considers four issues related to the model analyzed in section 2 . The first is the ability of shareholders and bondholders to design contracts that reduce the agency costs that otherwise arise due to incomplete contracting. The second is the legal process that accompanies default, and the associated possibility that bondholders may not be able to recover the full value of a firm's assets in the face of determined opposition by shareholders. The third is the potential incompleteness of tax carryforwards and carrybacks in settings with more than two periods. And the fourth is the applicability of the model to the case of foreign tax credits.

\subsection{Bond covenants.}

In principle, bondholders have available to them information that could be used to avoid some of the agency problems described in section 2 . The model in section 2 posits that lenders are unable to observe the investment mix chosen by borrowers. Another possibility is that lenders could attach covenants to bond contracts that specify the types of investments borrowers are permitted to undertake. Optimallychosen convenants would then be endogenous to the tax treatment of different assets, limiting the extent of permitted substitution into tax-preferred investments.

\footnotetext{
${ }^{10}$ Jensen and Meckling (1976) and Green (1984) analyze the incentives to undertake risky investments, Myers (1977) considers the role of debt overhang in discouraging safe investments, and Gertner and Scharfstein (1991) evaluate these incentives in the context of U.S. reorganization law.

${ }^{11}$ See, for example, Grossman and Hart (1982), Dewatripont and Tirole (1994), and Hart and Moore (1995).
} 
There are several well-known difficulties that such arrangements encounter in practice. ${ }^{12}$ The first stems from the difficulty of recontracting in stochastic environments. Borrowers will want to change their investment plans over time based on new information. If strictly enforced, covenants prevent efficient adaption to changing circumstances and thereby reduce the interest rates that borrowers are willing to pay. If not strictly enforced, then - in the absence of symmetric information between borrowers and lenders - covenants will not prevent excessive substitution into tax-preferred investments.

A second difficulty with bond covenants is that, in the presence of informational asymmetries, lenders will generally not have sufficient information to be able to write efficient covenants. Lenders may suspect that borrowers will adjust the composition of their investments in favor of assets that are eligible for tax credits, but do not know what fraction of the capital stock such assets would represent in the absence of tax incentives.

A third difficulty with bond covenants has to do with their enforcement. Covenant violations can lead to renegotiation or termination of bond contracts, but dramatic remedies are costly to all parties and may increase the chance of an even costlier subsequent default. Partly for this reason, it is common for lenders to waive violations of covenant provisions. ${ }^{13}$ From an ex ante standpoint, the potential costs associated with verifying compliance with covenant provisions and assessing damages for noncompliance reduces the desirability of attaching an excessive number of such restrictions to bond contracts.

In spite of these difficulties, it is possible for bondholders to impose restrictions on borrowers that could attenuate some of the effects analyzed in section 2 . For example, borrowing rates could be made contingent on the fraction of tax-preferred assets in which a borrower invests. This type of restriction would change somewhat the solution derived in section 2 without changing its character unless such contracts could be applied perfectly. In practice, the available evidence suggests that bond covenants cover only a limited range of behavior, primarily restricting the issuance of additional debt and the disposition of assets, and in no cases limiting the extent to which firms are permitted to invest in tax-preferred assets. ${ }^{14}$

\subsection{Default and bankruptcy.}

The model presented in section 2 contains a stylized treatment of the consequences of default. In the model, firms that are unable to meet contractual debt obligations become the property of bondholders; this ownership transfer does not otherwise affect the value of the ongoing concern. In practice, firm value may be adversely affected by the displacement of previous owners and by costs incurred during bankruptcy proceedings - and anticipation of such loss in value influences negotiations between

\footnotetext{
${ }^{12}$ See, for example, Smith and Warner (1979), McDaniel (1986), and Berlin and Loeys (1988).

${ }^{13}$ See, for example, Chen and Wei (1993) and Beneish and Press (1993).

${ }^{14}$ See the evidence reported by Smith and Warner (1979), Kalay (1982), McDaniel (1986), Lehn and Poulsen (1991), and Beneish and Press (1993).
} 
defaulting firms and their creditors. Consequently, creditors of financially distressed firms may accept terms in which they are paid less than the value of existing assets. ${ }^{15}$

It is possible to reinterpret the model's parameters to incorporate renegotiation and bankruptcy costs, as well as value transfers between bondholders and shareholders triggered by default. Costs associated with renegotiation and bankruptcy are reflected in reduced values of $\theta_{3}$. In the model's risk-neutral setting, the prospect of rent transfers from bondholders to shareholders of distressed firms is captured by higher than actual values of $\theta_{2}$ and corresponding lower values of $\theta_{3}$. Such changes do not alter the model's properties and implications, though they do affect its empirical application. ${ }^{16}$

\subsection{Timing of tax credits.}

In the two-period model analyzed in section 2, profitable firms receive the benefits of tax credits at the same time that uncertainty is resolved and bondholders are paid. In practice, certain tax credits are available when investments are made and prior to the resolution of uncertainty. ${ }^{17}$ There are two significant features of this difference. The first is that it is possible for firms that are ultimately unprofitable to benefit from tax credits if the credits are received enough years prior to subsequent losses that the tax law does not permit the losses to be carried back against the credits. Under U.S. law, net operating losses can be carried back only three years for tax purposes. Hence if an unprofitable firm's losses do not begin in earnest until more than three years after its initial investment, the firm benefits from any first-year credits.

There is a second aspect of tax credits received in the first year of an investment, which is that cash need not be disposed of in ways that are satisfactory to bondholders. In the absence of restrictions, credits received from tax-favored investments may be paid to shareholders as dividends or else invested in ways that benefit shareholders and not bondholders. If the firm defaults within the period of allowable carrybacks, the tax credit takes on the feature of a loan from the government that (from the standpoint of bondholders) shareholders are free to squander. Anticipating this, the bond market demands higher interest rates on loans to firms receiving up-front tax credits. Alternatively, lenders can insist on covenants that restrict the ability of borrowers to pay dividends, but such restrictions introduce other inefficiencies and are often not included in bond contracts. ${ }^{18}$

\footnotetext{
${ }^{15}$ Ang et al. (1982) document the administrative costs of corporate bankruptcies and subsequent liquidations. Franks and Torous (1989, 1994), Eberhardt et al. (1990), and Weiss (1990) offer evidence of the costs associated with recontracting and reorganization of firms in financial distress, and of value acquisition by shareholders in reorganizations.

${ }^{16}$ The results presented in the Appendix, in which $\theta$ is distributed continuously, rely on payoffs that are continuous in $\theta$. In order to apply the same analysis to cases in which firms incur default-related costs and resource transfers, it is necessary that such costs and transfers be continuous functions of the amount by which a firm defaults.

${ }^{17}$ An important exception is the foreign tax credit, which is the subject of the next section.

${ }^{18}$ Black and Scholes (1973) discuss the endogeneity of bond prices to anticipated dividend payout behavior. Smith and Warner (1979) report that only $23 \%$ of the bonds they examine (issued in 1974-75) restrict dividend payments; Kalay (1982) indicates that virtually all of the bond issues he analyzes have covenants limiting dividends; and McDaniel (1986) finds that, of the outstanding
} 
To formalize these ideas, suppose that $n$ years elapse between initial investment and the resolution of uncertainty (in the second period). A profitable firm receives a tax credit of $c \beta^{-n} \sigma_{1} K$ in the first period, in which $\beta=\frac{1}{1+d}>0$ is the firm's discount factor, and $d$ its annual rate of discount, so the tax credit is worth $c \sigma_{1} K$ in second-period terms. If the firm incurs a loss in the second period, then it is eligible to claim a refund for (nominal) taxes paid earlier. The fact that the firm received the tax credit in the first period reduces its second period refund by $c \beta^{-n} \sigma_{1} K$. Consequently, the tax credit is worth $c\left(1-\beta^{-n}\right) \sigma_{1} K$ in present value to a firm that is ultimately unprofitable. $n=\infty$ corresponds to situations in which default occurs beyond the time limit for tax carrybacks.

Consider the case in which a firm receiving a tax credit in the first period allocates a fraction $\gamma$ of the credit to its shareholders (in the form of dividends), with $(1-\gamma)$ remaining within the firm and therefore accessible to bondholders in the case of default in the second period. In this setting, shareholders benefit from tax credits even if the firm ultimately defaults. Hence, this modification changes equation (1) to:

$$
\begin{aligned}
\pi^{e}= & \left\{\left[Q(K, c) \theta_{1}-r(B, K, c)-\delta K\right](1-\tau)-B \tau+K+c K \sigma_{1}\right\} p_{1} \\
& +\left\{Q(K, c) \theta_{2}-r(B, K, c)+(1-\delta) K+c\left(1-\beta^{-n}\right) \sigma_{1} K\right\} p_{2} \\
& +\left\{\gamma c K \sigma_{1}\right\} p_{3} .
\end{aligned}
$$

Equation (7) is likewise affected, since bond market equilibrium must satisfy:

$(1+\bar{r}) B=\left(p_{1}+p_{2}\right) r(B, K, c)+p_{3}\left[Q(K, c) \theta_{3}+(1-\delta) K+c\left(1-\gamma-\beta^{-n}\right) \sigma_{1} K\right]$.

Imposing (24) and (25) changes the expression that appears on the right sides of equations (17) and (23); for example, (23) becomes:

$$
\begin{aligned}
\frac{d \pi^{e}}{d c} \frac{1}{K}= & {\left[p_{1}+\left(1-\beta^{-n}\right) p_{2}+\gamma p_{3}\right] \sigma_{1}(1-f \eta) } \\
& +\sigma_{1} \frac{p_{1}(1-\tau)+p_{2}}{p_{1}+p_{2}}\left(1-\gamma-\beta^{-n}\right) .
\end{aligned}
$$

The right side of equation (26) exhibits features similar to those of the right sides of (17) and (23). If $n=0$ and $\gamma=0$ then of course they are identical. If $n=\infty$ and $\gamma=0$ then the right side of $(26)$ becomes: $\left(p_{1}+p_{2}\right) \sigma_{1}\left(1+\frac{p_{1}(1-\tau)+p_{2}}{\left(p_{1}+p_{2}\right)^{2}}-f \eta\right)$, so a somewhat larger value of $f \eta$ is required for higher levels of $c$ to be associated with reduced investment and profitability. If $\gamma=\left(1-\beta^{-n}\right)$, then the right side of (26) becomes $\left[p_{1}+\left(1-\beta^{-n}\right)\left(p_{2}+p_{3}\right)\right] \sigma_{1}(1-f \eta)$, and again $f \eta=1$ is the critical value at which the effect of $c$ on investment and profitability changes sign. What these scenarios illustrate is that the implications of (17) and (23) apply generally to settings in which tax credits are received prior to the resolution of investment uncertainty.

bonds of Fortune 100 companies in 1984, only $35 \%$ restrict dividend payments, and Lehn and Poulsen (1991) report that, of the bonds they examine, $33 \%$ of those issued in 1986 and $45 \%$ of those issued in 1989 contain covenants restricting dividend payments. Interestingly, Kalay (1982) finds that most of the firms in his sample pay fewer dividends than their bond covenants permit. 


\subsection{Application to the foreign tax credit.}

The most important investment-related tax credit currently available in the United States is the foreign tax credit. The foreign tax credit system encourages American firms to substitute foreign for domestic investment to the detriment of bondholders, thereby raising the cost of domestic investment and possibly reducing total (domestic plus foreign) investment.

American corporations pay taxes to the United States on their foreign as well as domestic income, but are entitled to claim foreign tax credits for income taxes paid to foreign governments. The foreign tax credit mechanism implies that an American firm paying foreign taxes at rate $\tau^{*}$ faces a U.S. tax rate of $\left(\tau-\tau^{*}\right)$ on the same income. Since profitable firms therefore face the same total effective tax rate $(\tau)$ at home and abroad, shareholders have incentives to equate the pre-tax marginal products of capital located at home and abroad. ${ }^{19}$ The foreign subsidiary of an American firm must pay foreign taxes even if its domestic parent has losses. Consider the case in which a firm's foreign operation is profitable but its domestic operation may incur losses of sufficient magnitude to drive the whole firm into default. The firm's bondholders prefer that the after-foreign-tax marginal product of capital devoted to foreign investment be equated with the pre-tax marginal product of capital devoted to domestic investment. Since the incentives created by the foreign tax credit differ from these, borrowing rates rise, making investment more costly.

The foreign tax credit applies to income received from foreign sources and not to foreign investment per se. In order to evaluate the investment impact of the foreign tax credit, it is useful to cast the effect of the credit in terms of the notation used in section 2. Flows from abroad - representing after-foreign-tax profits of foreign subsidiaries - are subject to U.S. taxation at a rate equal to $\left(\tau-\tau^{*}\right) /\left(1-\tau^{*}\right)$. This tax treatment is equivalent to one in which firms are fully taxed by the United States on their after-foreign-tax foreign income but receive investment credits of $c^{f}$, in which $c^{f}$ is defined by:

$$
\frac{1-\left(\frac{\tau-\tau^{*}}{1-\tau^{*}}\right) z}{1-\left(\frac{\tau-\tau^{*}}{1-\tau^{*}}\right)}=\frac{1-c^{f}-\tau z}{1-\tau}
$$

The left side of (27) represents the U.S. tax adjustment to the user cost of capital for foreign investment (with returns defined net of foreign taxes) under the existing foreign tax credit system. The right side of (27) represents the tax adjustment to the user cost of capital for foreign investment in an alternate regime in which the return to foreign investment (net of foreign taxes) is fully taxed by the United States, but investors receive credits of $c^{f}$.

Equation (27) implies that $c^{f}=\tau^{*}(1-z)$. Making this substitution in (19), and using $\tau=\tau^{*}=0.35, f=1, \sigma_{1}=0.1, \delta=.08, \bar{r}=0.08$, and $\varepsilon=-1$, then $(1-f \eta)=0.76$. With otherwise the same parameters but $\varepsilon=-2,(1-f \eta)=0.52$. There is considerable interest in the degree to which firms substitute foreign for

\footnotetext{
${ }^{19}$ See Hines $(1994,1996)$ and Hines and Rice (1994) for more nuanced descriptions of the taxation of foreign-source income and analysis of the incentives it creates.
} 
domestic investment, though such substitution is typically measured in production terms. ${ }^{20}$ Values of $(1-f \eta)$ in the neighborhood of 0.5 imply that there is, in addition, a considerable amount of financial crowding out, as higher foreign tax credits reduce domestic investment by half of any increment to foreign investment.

\section{Evidence from the 1986 U.S. Tax Reform.}

There are several testable implications of the model described in section 2 . The model implies that appropriate specifications of the effects of tax policies on investment must account for the endogeneity of corporate borrowing rates. Such equations can be nested against more traditional specifications by estimating the extent to which the inter-asset composition of tax credits is related to their effect on aggregate investment demand. ${ }^{21}$

This section does not estimate investment equations, but instead considers the model's prior implication that corporate bond prices are affected by targeted tax credits. Evidence is provided by the U.S. Tax Reform Act of 1986 (TRA), which removed a number of targeted tax credits that were introduced in 1981. Most notably, the TRA eliminated the investment tax credit for new equipment purchases and changed depreciation schedules in a way that greatly reduced the preferential treatment of equipment over structures. As a consequence, the TRA provisions should benefit bondholders, and unanticipated favorable events surrounding passage of the TRA should be associated with abnormal positive returns in the corporate bond market.

Passage of a major U.S. tax reform in 1986 was anything but a foregone conclusion prior to its enactment by Congress. Cutler (1988) identifies two late-night events, the (favorable) vote on the floor of the House of Representatives on the evening of 17 December, 1985, and the (favorable) vote in the Senate Finance Committee on the evening of 6 May, 1986, as the milestones that made ultimate passage of the TRA a reality. Since these votes took place late at night, it is appropriate to treat market movements on each day following the votes as reflecting the news content of developments that were favorable for tax reform.

The stock market fell on the day after the House and Senate votes, and U.S. Treasury bond prices fell also. By contrast, corporate bond prices rose on the days following the favorable Congressional votes. Figure 3 depicts end-of-day indices of corporate bond prices (the Dow Jones industrial bond index), U.S. Treasury bond prices (the index of 10-year Treasury bonds), and stock prices (the S\&P500 index) on the trading days between 10 December, 1995 and 24 December, 1995. All three indices are normalized to equal 100 on 10 December. The vertical line in the figure denotes the evening of 17 December, and it is clear that prices of both Treasury bonds (marked by triangles) and stocks (squares) fall around the event, while corporate bond prices (circles) rise.

\footnotetext{
${ }^{20}$ See, for example, Altshuler and Cummins (1997), who report a -1.89 substitution elasticity of foreign and domestic capital.

${ }^{21}$ The specification is obtained by properly integrating (17).
} 
Figure 4 depicts the same indices on trading days around the Senate vote, specifically, between 29 April, 1986 and 13 May, 1986, with all indices normalized to equal 100 on 29 April. A similar pattern appears: the stock market and the U.S. Treasury bond market react negatively to the news on 7 May, while the corporate bond market rallies.

The regressions reported in Table 1 offer a somewhat more precise picture of market reactions to the Congressional votes. In these regressions, the dependent variable is the one-day percentage change in the Dow Jones industrial bond index. The sample period includes 144 trading days prior to the House vote, the period between the two votes, and 148 trading days following the Senate vote. Independent regressors include daily changes in yields of 10-year U.S. Treasury bonds and daily percentage changes in the Standard and Poor's 500 stock price index. In addition, two separate dummy variables are included, one for the day after the House vote, and one for the day after the Senate vote.

The results reported in Table 1 are consistent with the messages of Figures 3 and 4. Corporate bond price movements are negatively correlated with changes in Treasury bond yields, as they should be, and are positively correlated with changes in stock prices, though the latter correlation is not significant. Both the House and Senate votes are associated with significant positive innovations to corporate bond prices equal to roughly $0.17 \%$ of value. ${ }^{22}$

Additional evidence of the impact of the Tax Reform Act of 1986 is contained in the price reactions of corporate bonds of differing grades. Unfortunately, corporate bond yields are tabulated on a daily frequency only for the market as a whole, but Standard and Poor's (1988) reports weekly bond yields by grade over this period. Table 2 presents these data for periods surrounding the event dates.

The top panel of Table 2 reports bond yields for the second and fourth weeks of December, $1985 .^{23}$ Over this timespan, long-term Treasury yields fell by 16 basis points and short-term Treasury bond yields fell by one basis point. High-grade (AAA) industrial bond yields fell by 17 basis points, and lower-grade (A) corporate bonds by 39 basis points. Since Standard and Poor's does not report the maturity structure of the industrial bonds from which its indices are constructed, it is not clear to which Treasury bonds they are appropriately compared. ${ }^{24}$ Nevertheless, the evidence in the top panel of Table 2 suggests that the positive corporate bond market returns around the first event date are concentrated in lower-grade corporate bonds issued by firms with higher values of $f$.

The bottom panel of Table 2 reports bond yields for the first and second weeks

\footnotetext{
${ }^{22}$ The mean value of the Dow Jones industrial bond index over the sample period is 86.68 , to which the coefficients reported in Table 1 should be compared. The regression sample was not renormalized to equal 100 on dates prior to the legislative events.

${ }^{23}$ The two-week timespan is made necessary by the timing of the House vote. Standard and Poor's reports that its weekly indices are based on Wednesday closing prices or weekly averages. Since the House voted mid-week during the third week of December, and reported bond yields for that week may reflect pre-event or post-event pricing, the Table presents yields in the second and fourth weeks of December.

${ }^{24}$ Barclay and Smith (1995) find evidence that, controlling for other characteristics, lower-grade corporate bonds have longer maturities than do higher-grade corporate bonds.
} 
of May, 1986. Between these two weeks, long-term Treasury yields rose by 22 basis points and short-term Treasuries rose by 16 basis points. Over the same time period, high-grade industrial bond yields rose by one basis point and lower-grade corporate bond yields fell by four basis points. In May, as in December, the time period surrounding the event date is characterized by positive returns on corporate bonds relative to Treasuries, with the gains most pronounced in the prices of lower-grade corporate bonds.

The daily pricing depicted in Figures 3 and 4, along with the regressions reported in Table 1 and the evidence in Table 2, is consistent with the model described in section 2. Significant events enabling passage of the Tax Reform Act of 1986 coincide with reduced default premia on corporate bonds. It is worth noting, however, that this evidence comes from just two events. The regressions indicate that corporate bond price movements on the days following Congressional votes are unusually positive. In the absence of a much larger sample of tax reform events, it is not possible to rule out other possible explanations for these price reactions.

\section{Conclusion.}

The availability tax subsidies for investments in some assets and not others gives firms incentives to change the composition of their investments. Such substitution is inefficient, and, if anticipated, will raise borrowing costs, reduce the payoff to new investments, and thereby reduce the stimulatory effect of investment credits on aggregate investment. This effect is so strong that there are plausible circumstances in which greater investment credits are associated with reduced aggregate investment.

Aggregate investment studies typically find little evidence of stimulatory effects of tax credits on investment. Studies of disaggregated investment behavior report significant tax effects that reflect, at least in part, the ability of investors to substitute some asset types for others. The aggregate findings are consistent with firm-level evidence if asset substitutability reduces the aggregate effect of tax credits targeted at specific categories of investments. Evidence from market reactions to passage of the Tax Reform Act of 1986 also conforms to the predictions of the model. Corporate bonds had positive returns on the days after critical House and Senate votes, even though the stock market and the U.S. Treasury bond market fell on the same days.

The unequal taxation of differing assets is understood to distort the allocation of resources in society, and there are numerous studies of the magnitudes of these distortions in various settings. ${ }^{25}$ Summers (1987) challenges their implications, arguing that, since economies generally underinvest due to tax and other distortions, policies that affect the rate of investment have far greater influence on economic welfare than do policies that affect the composition of investment. What is not generally appreciated is the connection between these two considerations, that the distortionary nature of many tax subsidies influences the level as well as the composition of investment.

\footnotetext{
${ }^{25}$ See, for example, Harberger (1966), Shoven (1976), Boadway (1978), Gravelle (1981), Auerbach $(1983,1989)$, and Jorgenson and Yun $(1986,1990)$.
} 
The U.S. tax code currently offers far fewer incentives for specific categories of investments than it did prior to passage of the Tax Reform Act of 1986. Nevertheless, special credits are still available for various investments, of which foreign investment is the most important category. Little is known about the extent to which firms substitute foreign for domestic investment in response to the availability of foreign tax credits. To the degree that lenders anticipate such substitution, however, corporate borrowing rates are elevated and all investment becomes more costly. 


\section{Appendix.}

This appendix considers a generalization of the model to situations in which $\theta$ has a continuous distribution, thereby making the probability of bankruptcy $\left(p_{3}\right)$, the mean value of $\theta$ in bankruptcy states $\left(\theta_{3}\right)$, the associated probabilities $p_{1}$ and $p_{2}$, and the values of $\theta_{1}$ and $\theta_{2}$ endogenous to $c$ and to actions taken by firms. As it happens, this generalization does not change any of the results described in the text. While it is perhaps obvious that the envelope theorem, together with payoffs to shareholders and bondholders that are continuous in $\theta$, might produce such a result, the tax treatment of gains and losses is sufficiently asymmetric as to create concern that some of the results derived in the text are artifacts of the assumption that $p_{1}, p_{2}$, and $p_{3}$ take fixed values. The purpose of the appendix is to evaluate this possibility.

Consider the effect of $c$ on profitability, as analyzed in section 2.4 , but with $\theta$ distributed continuously. Differentiating the bond market equation (7) produces:

$$
\begin{aligned}
0= & \left(p_{1}+p_{2}\right) \frac{\partial r(B, K, c)}{\partial c}+p_{3} \theta_{3} \frac{\partial Q(K, c)}{\partial c} \\
& +r(B, K, c) \frac{d\left(p_{1}+p_{2}\right)}{d c}+Q(K, c) \frac{d\left(p_{3} \theta_{3}\right)}{d c}+(1-\delta) K \frac{d p_{3}}{d c} .
\end{aligned}
$$

It is convenient to define $\widehat{\theta}_{3}$ as the value of $\theta$ at which the firm is on the verge of bankruptcy:

$$
\widehat{\theta}_{3} \equiv \frac{r(B, K, c)-(1-\delta) K}{Q(K, c)}
$$

Then $p_{3}$ equals:

$$
p_{3}=\int_{0}^{\widehat{\theta}_{3}} g(\theta) d \theta
$$

and $\theta_{3}$ is given by:

$$
\theta_{3}=\frac{1}{p_{3}} \int_{0}^{\widehat{\theta}_{3}} \theta g(\theta) d \theta
$$

Differentiating these conditions,

$$
\begin{gathered}
\frac{d p_{3}}{d c}=-\frac{d\left(p_{1}+p_{2}\right)}{d c}=g\left(\widehat{\theta}_{3}\right) \frac{d \widehat{\theta}_{3}}{d c}, \\
\frac{d\left(p_{3} \theta_{3}\right)}{d c}=\widehat{\theta}_{3} g\left(\hat{\theta}_{3}\right) \frac{d \widehat{\theta}_{3}}{d c} .
\end{gathered}
$$

Imposing (29), (30), and (31), the second line of (28) becomes:

$$
\begin{aligned}
& r(B, K, c) \frac{d\left(p_{1}+p_{2}\right)}{d c}+Q(K, c) \frac{d\left(p_{3} \theta_{3}\right)}{d c}+(1-\delta) K \frac{d p_{3}}{d c} \\
= & \left\{-r(B, K, c)+Q(K, c) \widehat{\theta}_{3}+(1-\delta) K\right\} g\left(\widehat{\theta}_{3}\right) \frac{d \widehat{\theta}_{3}}{d c} \\
= & 0
\end{aligned}
$$


Then (28) and (32) imply that:

$$
\left(p_{1}+p_{2}\right) \frac{\partial r(B, K, c)}{\partial c}+p_{3} \theta_{3} \frac{\partial Q(K, c)}{\partial c}=0
$$

which is identical to equation (20) in section 2.4. Straightforward application of the envelope theorem then implies that:

$$
\frac{\partial r(B, K, c)}{\partial c}=K \frac{d \sigma_{1}}{d c} c p_{1} \frac{p_{3} \theta_{3}}{\left[p_{1} \theta_{1}(1-\tau)+p_{2} \theta_{2}\right]\left[p_{1}+p_{2}\right]}
$$

which is identical to equation (21) in section 2.4 .

Applying the envelope theorem to (1), the effect of $c$ on expected profits is:

$$
\begin{aligned}
\frac{d \pi^{e}}{d c}= & -\frac{\partial r(B, K, c)}{\partial c}\left[p_{1}(1-\tau)+p_{2}\right]+K \sigma_{1} p_{1} \\
& +\left\{K\left(1+c \sigma_{1}\right)-B \tau-[r(B, K, c)+\delta K](1-\tau)\right\} \frac{d p_{1}}{d c} \\
& +Q(K, c)(1-\tau) \frac{d\left(p_{1} \theta_{1}\right)}{d c} \\
& +[(1-\delta) K-r(B, K, c)] \frac{d p_{2}}{d c}+Q(K, c) \frac{d\left(p_{2} \theta_{2}\right)}{d c} .
\end{aligned}
$$

The value of is $p_{1}$ given by:

$$
p_{1}=\int_{\widehat{\theta}_{1}}^{\infty} g(\theta) d \theta
$$

in which $\widehat{\theta}_{1}$ is the value of $\theta$ at which the firm is on the verge of having taxable profits:

$$
\widehat{\theta}_{1} \equiv \frac{\frac{c K \sigma_{1}}{\tau}+\delta K+r(B, K, c)-B}{Q(K, c)} .
$$

This definition implies that $\theta_{1}$ is:

$$
\theta_{1}=\frac{1}{p_{1}} \int_{\widehat{\theta}_{1}}^{\infty} \theta g(\theta) d \theta .
$$

Consequently,

and

$$
\frac{d p_{1}}{d c}=-g\left(\widehat{\theta}_{1}\right) \frac{d \widehat{\theta}_{1}}{d c}
$$

$$
\frac{d\left(p_{1} \theta_{1}\right)}{d c}=-\widehat{\theta}_{1} g\left(\widehat{\theta}_{1}\right) \frac{d \widehat{\theta}_{1}}{d c} .
$$

The value of is $p_{2}$ given by:

$$
p_{2}=\int_{\widehat{\theta}_{3}}^{\widehat{\theta}_{1}} g(\theta) d \theta,
$$

and $\theta_{2}$ is:

$$
\theta_{2}=\frac{1}{p_{2}} \int_{\hat{\theta}_{3}}^{\widehat{\theta}_{1}} \theta g(\theta) d \theta
$$


Therefore,

$$
\frac{d p_{2}}{d c}=g\left(\widehat{\theta}_{1}\right) \frac{d \widehat{\theta}_{1}}{d c}-g\left(\widehat{\theta}_{3}\right) \frac{d \widehat{\theta}_{3}}{d c}
$$

and

$$
\frac{d\left(p_{2} \theta_{2}\right)}{d c}=\widehat{\theta}_{1} g\left(\widehat{\theta}_{1}\right) \frac{d \widehat{\theta}_{1}}{d c}-\widehat{\theta}_{3} g\left(\widehat{\theta}_{3}\right) \frac{d \widehat{\theta}_{3}}{d c} .
$$

Applying (37) and (38) to the second and third lines of (35) yields:

$$
\begin{aligned}
& \left\{K\left(1+c \sigma_{1}\right)-B \tau-[r(B, K, c)+\delta K](1-\tau)\right\} \frac{d p_{1}}{d c}+Q(K, c)(1-\tau) \frac{d\left(p_{1} \theta_{1}\right)}{d c} \\
= & \left\{K\left(1+c \sigma_{1}\right)-B \tau-[r(B, K, c)+\delta K](1-\tau)+Q(K, c) \widehat{\theta}_{1}(1-\tau)\right\} \frac{d p_{1}}{d c} \\
= & \left\{K\left(1+\frac{c \sigma_{1}}{\tau}\right)+B\right\}\left[-g\left(\widehat{\theta}_{1}\right)\right] \frac{d \widehat{\theta}_{1}}{d c} .
\end{aligned}
$$

Using (39) and (40), the fourth line of (35) becomes:

$$
\begin{aligned}
& {[(1-\delta) K-r(B, K, c)] \frac{d p_{2}}{d c}+Q(K, c) \frac{d\left(p_{2} \theta_{2}\right)}{d c} } \\
= & \left\{(1-\delta) K-r(B, K, c)+Q(K, c) \widehat{\theta}_{1}\right\} g\left(\widehat{\theta}_{1}\right) \frac{d \widehat{\theta}_{1}}{d c} \\
& -\left\{(1-\delta) K-r(B, K, c)+Q(K, c) \widehat{\theta}_{3}\right\} g\left(\widehat{\theta}_{3}\right) \frac{d \widehat{\theta}_{3}}{d c} \\
= & \left\{K\left(1+\frac{c \sigma_{1}}{\tau}\right)+B\right\} g\left(\widehat{\theta}_{1}\right) \frac{d \widehat{\theta}_{1}}{d c}
\end{aligned}
$$

Combining (35), (41), and (42) produces:

$$
\frac{d \pi^{e}}{d c}=-\frac{\partial r(B, K, c)}{\partial c}\left[p_{1}(1-\tau)+p_{2}\right]+K \sigma_{1} p_{1}
$$

Together with (34), (43) implies:

$$
\frac{d \pi^{e}}{d c} \frac{1}{K}=p_{1} \sigma_{1}(1-f \eta)
$$

which is identical to (23) in section 2.4. Consequently, endogeneity of the bankruptcy probability leaves unchanged the results derived earlier in the paper. Endogenizing the bankruptcy probability may, however, affect the interpretation of the results, since the equilibrium value of $f$ is a function of $c$. 


\section{References}

Altshuler, Rosanne and Alan J. Auerbach, 1990, The significance of tax law asymmetries: An empirical investigation, Quarterly Journal of Economics, 105, 61-86.

Altshuler, Rosanne and Jason G. Cummins, 1997, Tax policy and the dynamic demand for domestic and foreign capital by multinational corporations, working paper 97-4, Technical Committee on Business Taxation, Ottawa, Canada.

Ang, James S., Jess H. Chua, and John J. McConnell, 1982, The administrative costs of corporate bankruptcy: A note, Journal of Finance, 37, 219-226.

Auerbach, Alan J., 1983, Corporate taxation in the United States, Brookings Papers on Economic Activity, 2, 451-505.

Auerbach, Alan J., 1986, The dynamic effects of tax law asymmetries, Review of Economic Studies, 53, 205-225.

Auerbach, Alan J., 1989, The deadweight loss from 'non-neutral' capital income taxation, Journal of Public Economics, 40, 1-36.

Auerbach, Alan J. and Kevin Hassett, 1992, Tax policy and business fixed investment in the United States, Journal of Public Economics, 47, 141-170.

Auerbach, Alan J. and James M. Poterba, 1987, Tax loss carryforwards and corporate tax incentives, in Martin Feldstein ed., The effects of taxation on capital accumulation (Chicago: University of Chicago Press).

Auerbach, Alan J. and David Reishus, 1988, The effects of taxation on the merger decision, in Alan J. Auerbach ed., Corporate takeovers: Causes and consequences (Chicago: University of Chicago Press).

Barclay, Michael J. and Clifford W. Smith, Jr., 1995, The maturity structure of corporate debt, Journal of Finance, 50, 609-631.

Beneish, Massod D. and Eric Press, 1993, Costs of technical violation of accounting-based debt covenants, Accounting Review, 68, 233-257.

Berlin, Mitchell and Jan Loeys, 1988, Bond covenants and delegated monitoring, Journal of Finance, 43, 397-412.

Black, Fischer and Myron Scholes, 1973, The pricing of options and corporate liabilities, Journal of Political Economy, 81, 637-654.

Boadway, Robin, 1978, Investment incentives, corporate taxation, and efficiency in the allocation of capital, Economic Journal, 88, 470-481.

Chen, Kevin and John Wei, 1993, Creditors' decisions to waive violations of accounting-based debt covenants, Accounting Review, 68, 218-232. 
Chirinko, Robert S., 1993, Business fixed investment spending: Modeling strategies, empirical results, and policy implications, Journal of Economic Literature, 31, 1875-1911.

Cummins, Jason G., Kevin A. Hassett, and R. Glenn Hubbard, 1994, A reconsideration of investment behavior using tax reforms as natural experiments, Brookings Papers on Economic Activity, 2, 1-59.

Cutler, David M., 1988, Tax reform and the stock market: An asset price approach, American Economic Review, 78, 1107-1117.

DeAngelo, Harry and Ronald W. Masulis, 1980, Optimal capital structure under corporate and personal taxation, Journal of Financial Economics, 8, 3-29.

Dewatripont, Mathias and Jean Tirole, 1994, A theory of debt and equity: Diversity of securities and manager-shareholder congruence, Quarterly Journal of Economics, 109, 1027-1054.

Eberhardt, Allan C., William T. Moore, and Rodney L. Roenfeldt, 1990, Security pricing and deviations from the absolute priority rule in bankruptcy proceedings, Journal of Finance, 45, 1457-1469.

Franks, Julian R. and Walter N. Torous, 1989, An empirical investigation of U.S. firms in reorganization, Journal of Finance, 44, 747-769.

Franks, Julian R. and Walter N. Torous, 1994, A comparison of financial recontracting in distressed exchanges and Chapter 11 reorganizations, Journal of Financial Economics, 35, 349-370.

Gertner, Robert and David Scharfstein, 1991, A theory of workouts and the effects of reorganization law, Journal of Finance, 46, 1189-1222.

Gilson, Stuart C., 1990, Bankruptcy, boards, banks, and blockholders: Evidence on changes in corporate ownership and control when firms default, Journal of Financial Economics, 27, 355-387.

Goolsbee, Austan, 1998, Investment tax incentives, prices, and the supply of capital goods, Quarterly Journal of Economics, 113, 121-148.

Gravelle, Jane G., 1981, The social cost of nonneutral taxation: Estimates for nonresidential capital, in Charles R. Hulten ed., Depreciation, inflation, and the taxation of income from capital (Washington, DC: Urban Institute).

Green, Richard C., 1984, Investment incentives, debt, and warrants, Journal of Financial Economics, 13, 115-136.

Grossman, Sanford J. and Oliver D. Hart, 1982, Corporate financial structure and managerial incentives, in John J. McCall ed., The economics of information and uncertainty (Chicago: University of Chicago Press). 
Hall, Robert E. and Dale W. Jorgenson, 1967, Tax policy and investment behavior, American Economic Review, 57, 391-414.

Hall, Robert E. and Dale W. Jorgenson, 1971, Application of the theory of optimum capital accumulation, in Gary Fromm ed., Tax incentives and capital spending (Washington, DC: Brookings).

Harberger, Arnold C., 1966, Efficiency effects of taxes on income from capital, in Marian Krzyzaniak ed., Effects of corporation income tax (Detroit: Wayne State University Press).

Hart, Oliver and John Moore, 1994, A theory of debt based on the inalienability of human capital, Quarterly Journal of Economics, 109, 841-879.

Hart, Oliver and John Moore, 1995, Debt and seniority: An analysis of the role of hard claims in constraining management, American Economic Review, 85, 567-585.

Hines, James R., Jr., 1994, Credit and deferral as international investment incentives, Journal of Public Economics, 55, 323-347.

Hines, James R., Jr., 1996, Altered states: Taxes and the location of foreign direct investment in America, American Economic Review, 86, 1076-1094.

Hines, James R., Jr. and Eric M. Rice, 1994, Fiscal paradise: Foreign tax havens and American business, Quarterly Journal of Economics, 109, 149-182.

Hotchkiss, Edith Shwalb, 1995, Postbankruptcy performance and management turnover, Journal of Finance, 50, 3-21.

Jensen, Michael C. and William H. Meckling, 1976, Theory of the firm: Managerial behavior, agency costs and ownership structure, Journal of Financial Economics, 3, 305-360.

Jorgenson, Dale W. and Kun-Young Yun, 1986, Tax policy and capital allocation, Scandinavian Journal of Economics, 88, 355-377.

Jorgenson, Dale W. and Kun-Young Yun, 1990, Tax reform and U.S. economic growth, Journal of Political Economy, 98, S151-S193.

Kalay, Avner, 1982, Stockholder-bondholder conflict and dividend constraints, Journal of Financial Economics, 10, 211-233.

Kwan, Simon H., 1996, Firm-specific information and the correlation between individual stocks and bonds, Journal of Financial Economics, 40, 63-80.

Lehn, Kenneth and Annette Poulsen, 1991, Contractual resolution of bondholder-stockholder conflicts in leveraged buyouts, Journal of Law and Economics, 34, 645-673. 
Majd, Saman and Stewart C. Myers, 1987, Tax asymmetries and corporate tax reform, in Martin Feldstein ed., The effects of taxation on capital accumulation (Chicago: University of Chicago Press).

McDaniel, Morey W., 1986, Bondholders and corporate governance, Business Lawyer, 41, 413-460.

Miller, Merton H., 1977, Debt and taxes, Journal of Finance, 32, 261-275.

Mintz, Jack, 1988, An empirical estimate of corporate tax refundability and effective tax rates, Quarterly Journal of Economics, 103, 225-231.

Modigliani, Franco and Merton H. Miller, 1963, Corporate income taxes and the cost of capital: A correction, American Economic Review, 53, 433-443.

Myers, Stewart C., 1977, The determinants of corporate borrowing, Journal of Financial Economics, 5, 147-175.

Shoven, John B., 1976, The incidence and efficiency effects of taxes on income from capital, Journal of Political Economy, 84, 1261-1283.

Smith, Clifford W., Jr. and Jerold B. Warner, 1979, On financial contracting: An analysis of bond covenants, Journal of Financial Economics, 7, 117-161.

Standard and Poor's, 1988, Standard and Poor's security price index record (New York: Standard and Poor's).

Stiglitz, Joseph E., 1973, Taxation, corporate financial policy, and the cost of capital, Journal of Public Economics, 2, 1-34.

Summers, Lawrence H., 1987, Should tax reform level the playing field?, in Proceedings of the seventy-ninth annual conference (Columbus, $\mathrm{OH}$ : National Tax Association).

Weiss, Lawrence A., 1990, Bankruptcy resolution: Direct costs and violation of priority claims, Journal of Financial Economics, 27, 285-314. 


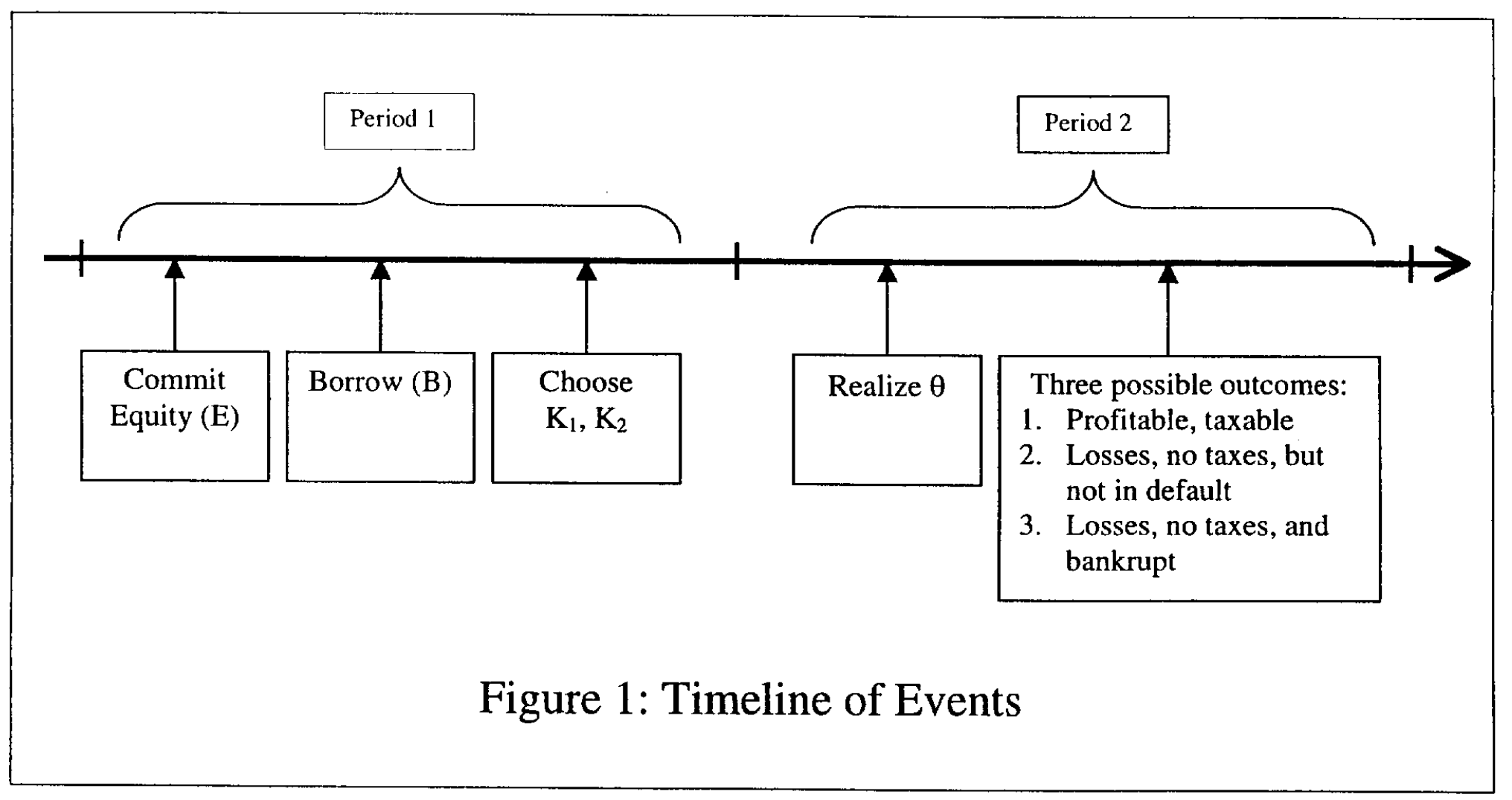




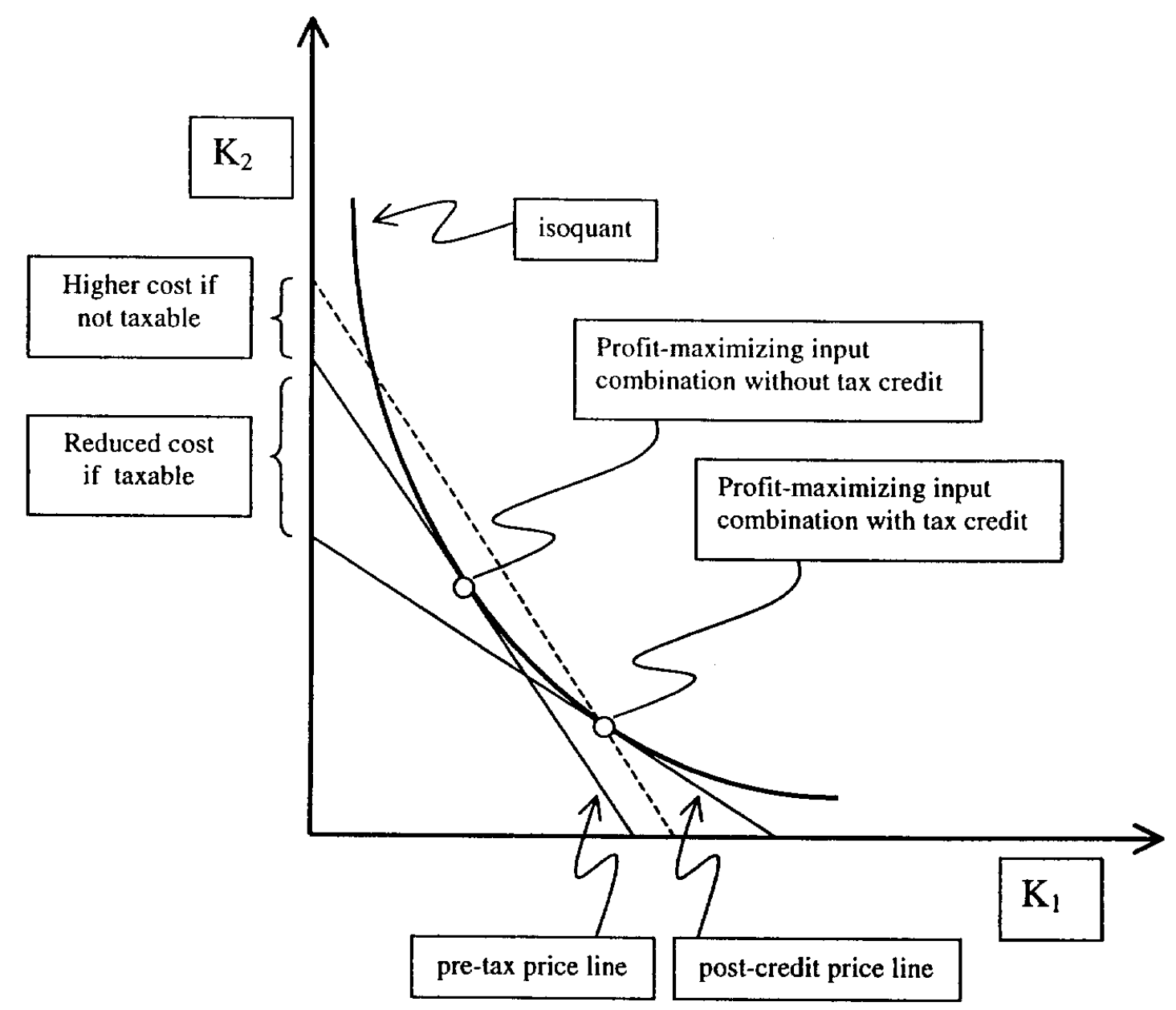

Figure 2: Credit-induced Cost Changes along an Isoquant 


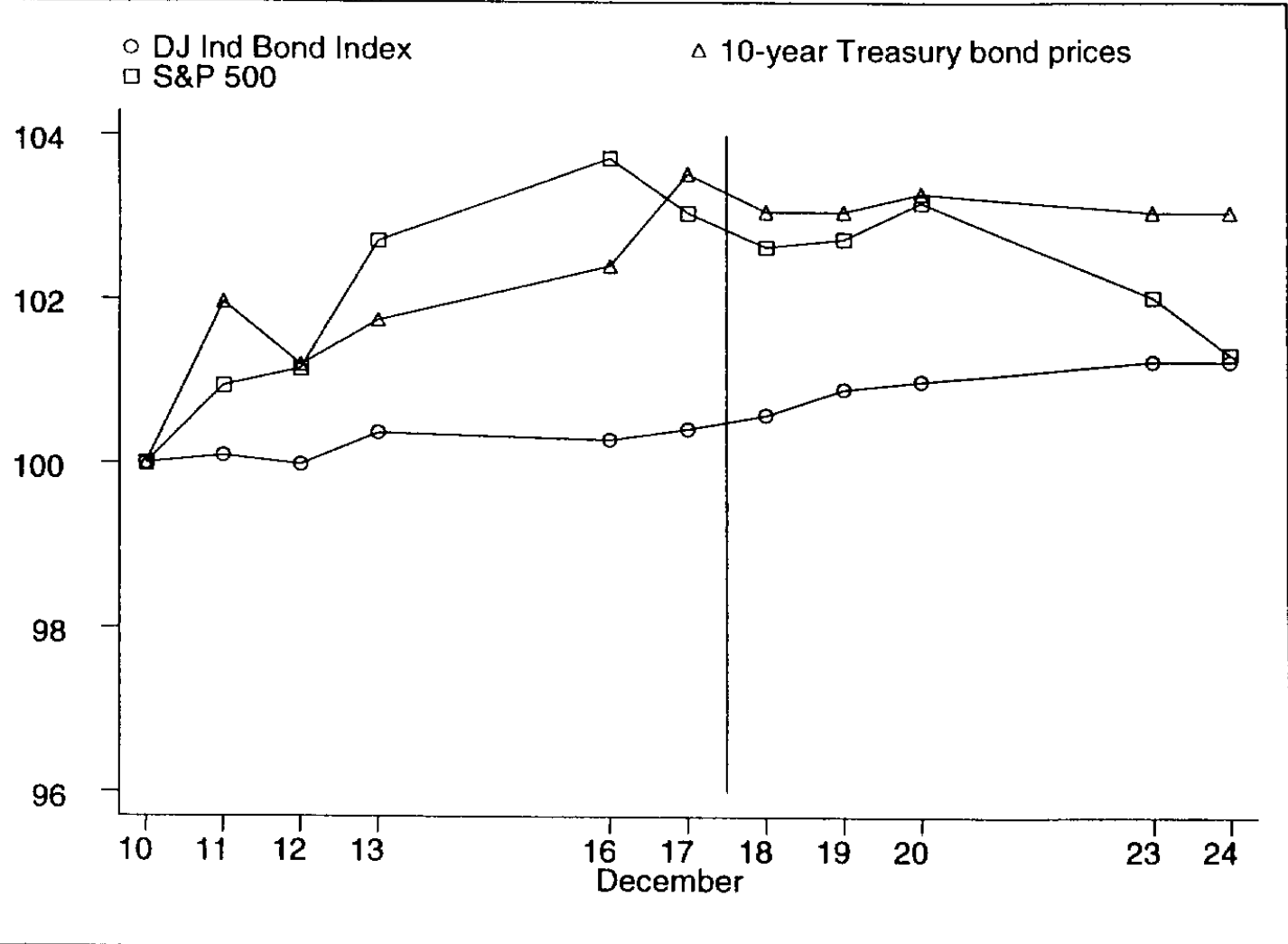

Figure 3: Standard and Poor's 500 index, 10-year US Treasury bond price index, and Dow Jones Industrial Bond index closing values, indexed to 100 on 10 December, for days surrounding the House Vote on the evening of 17 December, 1985.

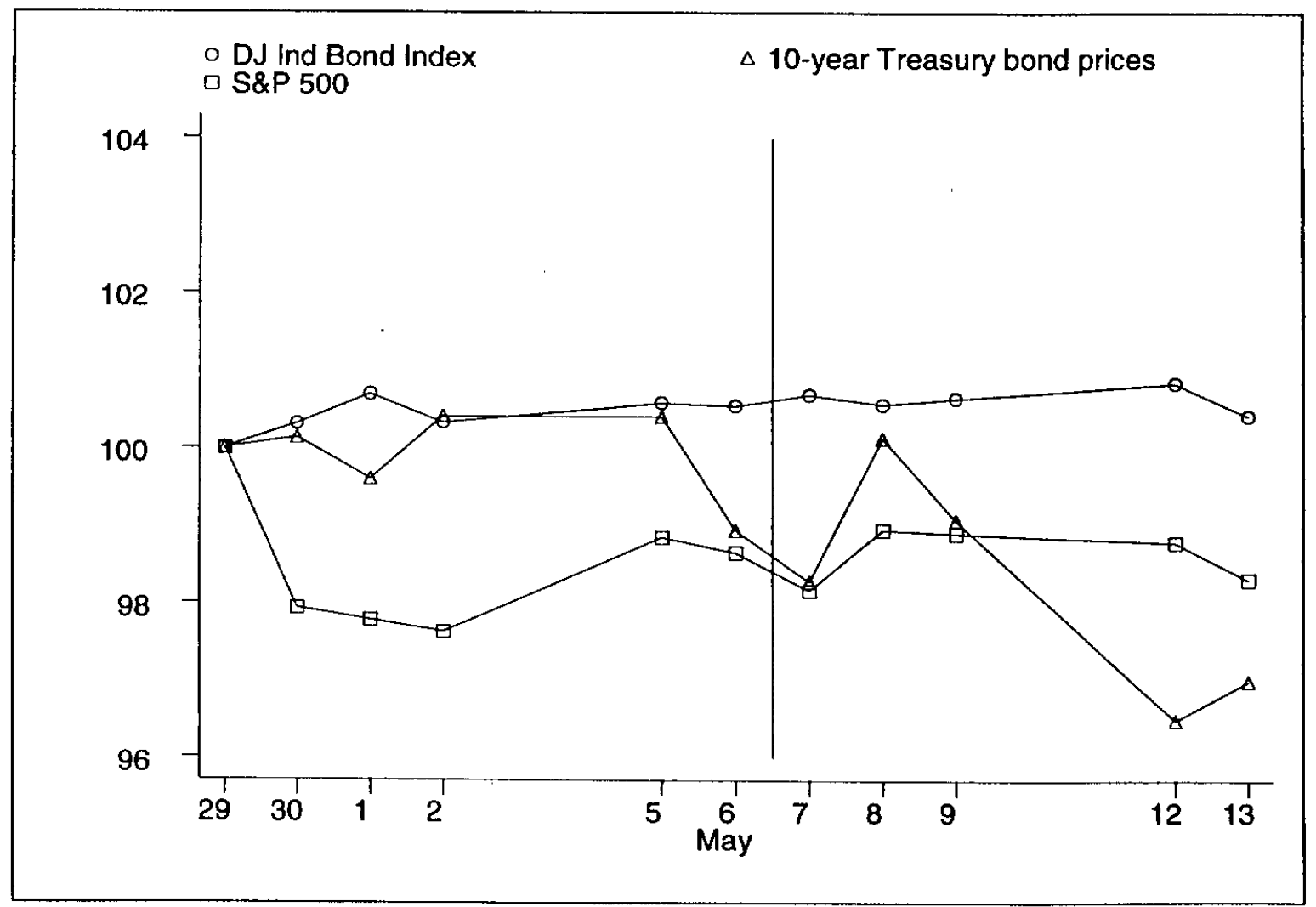

Figure 4: Standard and Poor's 500 index, 10-year US Treasury bond price index, and Dow Jones Industrial Bond index closing values, indexed to 100 on 29 April, for days surrounding the Senate Vote on the evening of 6 May, 1986. 
Table 1

Corporate Bond Price Reactions to the Tax Reform Act of 1986

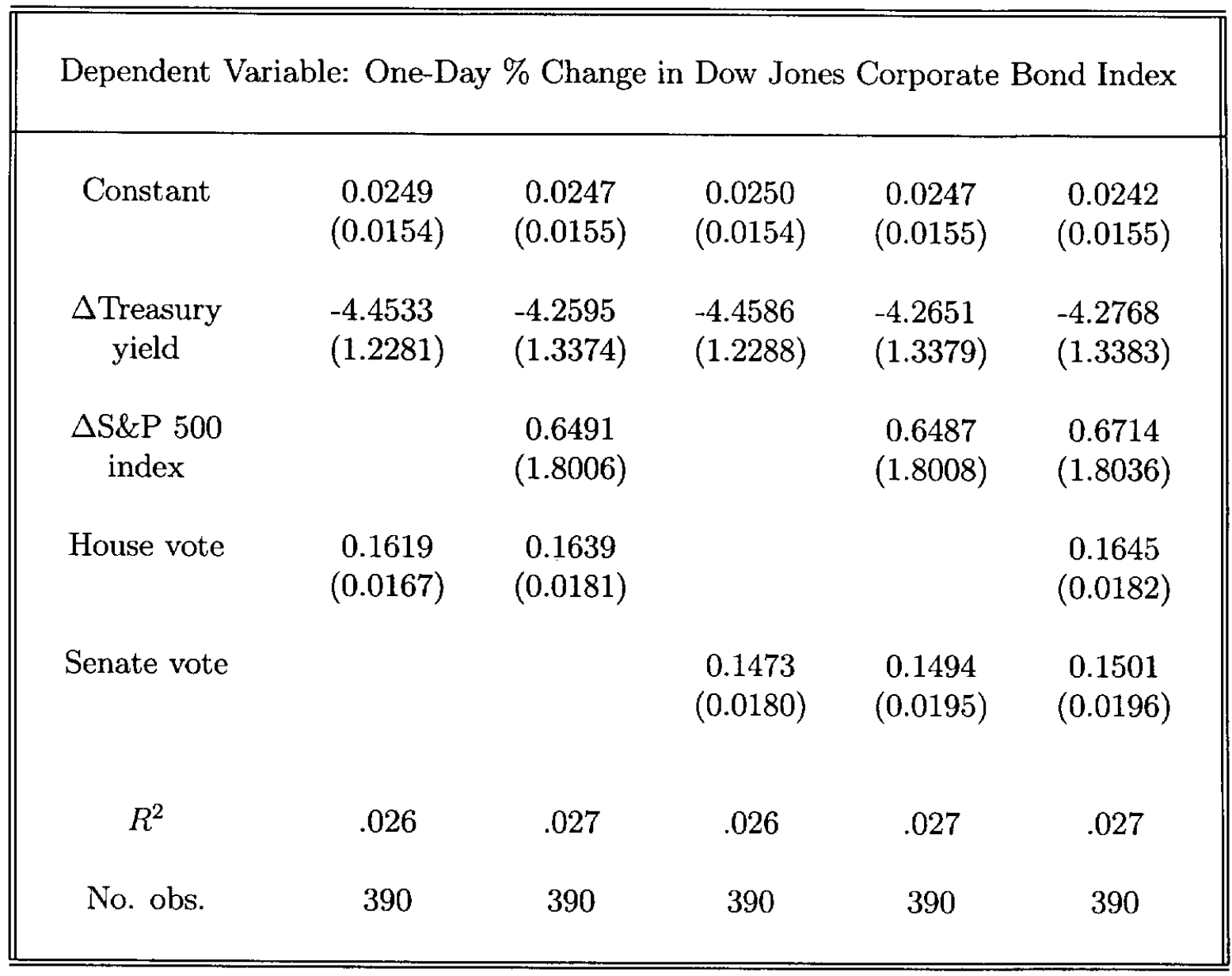

Note to Table 1: The columns report coefficients from OLS regressions in which the dependent variable is the daily percent change in the Dow Jones corporate bond price index. The sample includes all trading days between 144 trading days prior to the House vote (of 17 December, 1985) and 148 days following the Senate vote (of 6 May, 1986). The variable " $\Delta$ Treasury yield" is the daily change in the yield of 10-year U.S. Treasury bonds. The variable " $\triangle \mathrm{S} \& \mathrm{P} 500$ Index" is the daily percent change in the Standard and Poor's 500 stock price index. The dummy variable "House vote" equals 1 on 18 December 1985 and zero otherwise; the dummy variable "Senate vote" equals 1 on 7 May 1986 and zero otherwise. The mean of the dependent variable is 0.0294 and its standard deviation 0.3059 ; the variable " $\Delta$ Treasury yield" has a mean of -0.0910 and a standard deviation of 1.1043 ; and the variable " $\Delta S \& P 500$ Index" has a mean of 0.0692 and a standard deviation of 0.8296 . White standard errors are in parentheses. 
Table 2

Bond Yields in Weeks around Event Dates

\begin{tabular}{|c|c|c|c|c|}
\hline \multicolumn{5}{|l|}{ Event: 17 December, 1985} \\
\hline & \multicolumn{2}{|c|}{ Treasury yields } & \multicolumn{2}{|c|}{ Corporate yields } \\
\hline & long term & short term & AAA & A \\
\hline Second Week of December & 9.45 & 8.17 & 9.80 & 10.59 \\
\hline \multirow[t]{4}{*}{ Fourth Week of December } & 9.29 & 8.16 & 9.63 & 10.20 \\
\hline & & & & \\
\hline & \multicolumn{2}{|c|}{ Treasury yields } & \multicolumn{2}{|c|}{ Corporate yields } \\
\hline & long term & short term & AAA & $\mathrm{A}$ \\
\hline First week of May & 7.83 & 7.16 & 9.18 & 9.74 \\
\hline Second week of May & 8.05 & 7.32 & 9.19 & 9.70 \\
\hline
\end{tabular}

Note to Table 2: The table presents annualized yields of Treasury bonds and corporate bonds for periods surrounding Congressional votes on passage of the Tax Reform Act of 1986. The late-night votes on the floor of the House of Representatives on 17 December, 1985, and in the Senate Finance Committee on 6 May, 1986 are the events considered in the table. The first column presents yields to maturity of representative taxable U.S. government bonds of long (more than ten years) maturity. The second column presents yields to maturity of representative taxable U.S. government bonds of short (3-4 year) maturity. The third column presents yields to maturity of representative industrial bonds (of differing maturities) rated AAA. The fourth column presents yields to maturity of representative industrial bonds (of differing maturities) rated $\mathrm{A}$.

Source: Standard and Poor's (1988). 